\title{
Taiwan left isolated in fight against SARS
}

David Cyranoski, Tokyo

Researchers in Taiwan say they are being shut out of the global investigation into the pneumonia-like disease that is sweeping the world because their country isn't recognized by the World Health Organization (WHO), which is coordinating the study.

Mei-Shang Ho, an epidemiologist at Taiwan's Academia Sinica, is one of several researchers who say they have been denied access to samples and information. Ho wanted more data on severe acute respiratory syndrome (SARS) after it affected two Taiwanese patients in early March. But WHO officials told Ho and other investigators that they should instead approach the People's Republic of China in Beijing, which the organization does recognize.

"Knowing the information is there but not being able to get it is truly frustrating," says Ho, who decided to travel to Beijing last week to get first-hand data on the disease's spread. "We can't get any information from the WHO," says Yuan-Tsong Chen, director of the Institute of Biomedical Sciences at the Academia Sinica in Taipei.

China has never recognized the government of Taiwan, where Chinese nationalists retreated when the communists won control of the mainland in 1949. It considers Taiwan to be its province, and since 1972, when the United Nations admitted the communist government in Beijing, the WHO and other bodies have denied Taiwan membership.

Unable to participate in meetings between the WHO's collaborating centres, Taiwan's researchers must rely on the WHO's website.

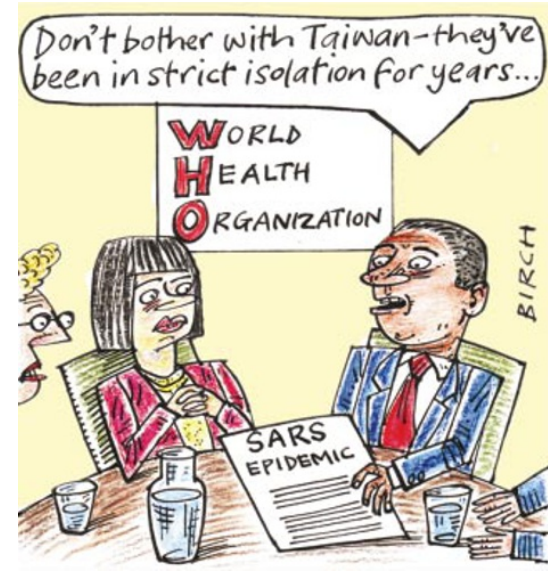

"By the time the information is in the public domain, it's probably out of date," says Chen. WHO officials are keen to visit mainland China, but have not asked to visit Taiwan.

Taiwanese researchers say they have also struggled to obtain materials such as diagnostic reagents. To test Taiwan's 23 probable SARS cases for the coronavirus thought to be responsible, researchers wanted to use antibody tests distributed by the WHO. "We were told to go to Beijing," says Chien-Jen Chen, an epidemiologist at National Taiwan University and chair of the island's SARS advisory committee.

The WHO says its hands are tied because Taiwan is not a member. Iain Simpson, a WHO spokesman in Geneva, says that the organization arranged for Taiwan to receive a visitor from the Centers for Disease Con- trol and Prevention in Atlanta, Georgia, one of its collaborating centres. "There's little more that we can do," he adds.

Government officials are highlighting the situation to promote Taiwan's case for full representation at the United Nations and the WHO. "We share our public-health officials" anger that for political reasons we are denied access to the world health system," said Parris Chang, a legislator with Taiwan's ruling Democratic Progressive Party, on a visit to Washington DC last week. He added that Taiwan is demanding observer status at the World Health Assembly, the WHO's governing body.

Congressman Sherrod Brown (Democrat, Ohio) backed Chang and called for the United States to support the recognition of Taiwan more vigorously. Taiwan's current plight is an "unjustified violation of the basic human right to healthcare", says Brown.

Despite its isolation, Taiwan seems to be dealing successfully with the epidemic. Since mid-March, when the first cases were recognized, it has reported one new case a day, compared with five each day in Singapore and 40 in Hong Kong. There have been no deaths.

Taiwanese researchers have also enjoyed some collaborative success. A Taiwanese group was involved in a study that isolated the coronavirus from patients in Taiwan and elsewhere (T. G. Ksiazek et al. N. Engl. J. Med. doi:10.1056/NEJMoa030781;2003).

- Researchers at Canada's Michael Smith Genome Sciences Centre in Vancouver, British Columbia, said on 12 April that they have sequenced the coronavirus that is thought to cause SARS (www.bcgsc.bc.ca).

\section{Infection risk puts the brakes on Canada's biomedical research}

The epidemic of severe acute respiratory syndrome (SARS) is freezing up biomedical research in Toronto, Canada, as medical-school administrators are forced to reduce access to hospital buildings. And the situation is being eyed nervously by colleagues in the United States and elsewhere, who fear similar consequences as the spread of the mystery illness continues.

"When they started taking our temperatures we knew it was getting serious," says Stephen Scherer, a geneticist at Toronto's Hospital for Sick Children. But for Scherer and other scientists at Toronto's research hospitals, a nurse's check-up as they arrive each day is just the start of the problem.

To contain the spread of the disease from sufferers admitted to the hospital and staff working there, all non-essential staff at Scherer's institute and the nearby Mount Sinai Hospital are being encouraged to stay at home.

Researchers determined to get to work must join queues at the hospital's entrances, pass a SARS screening test and wear a surgical mask while in the hospital. Meetings of researchers are banned, even outside hospital grounds.

"There's been massive disruption," says Michael Tyers, a cell biologist at Mount Sinai's Samuel Lunenfeld Research Institute. "Many of the projects in my lab have been compromised."

Until researchers figure out the exact cause of SARS, and how it spreads, disruption is likely to continue. The needs of researchers will take second place to the need to contain the disease, says infection-control specialist Mark Loeb of McMaster University in Hamilton, Ontario, who is advising Toronto's hospitals on controlling SARS.

Many researchers who have no direct contact with patients still like to rub shoulders with clinical staff, and administrators think that this helps to assure the research's clinical relevance. But the SARS outbreak is giving some researchers second thoughts. "I'm starting to question the point of working in a research hospital," says Tyers.

Cell-signalling researcher Tony Pawson, research director of the Samuel Lunenfeld

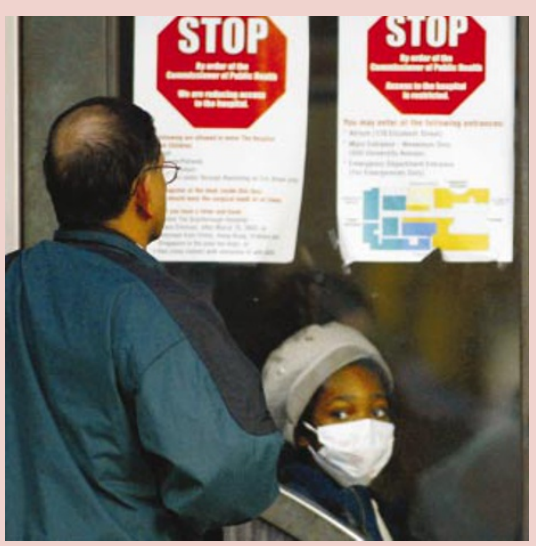

Warning signs: access to the Hospital for Sick Children in Toronto is temporarily restricted.

institute, says he is optimistic that the SARS outbreak will abate before researchers walk out. "But it raises a lot of issues about hospitals being used as thoroughfares," he says. Tom Clarke 